\title{
Pazopanib-induced hyperbilirubinemia is associated with Gilbert's syndrome UGTIAI polymorphism
}

\author{
C-F Xu', , BH Reck', Z Xue', L Huang', KL Baker², M Chen², EP Chen ${ }^{3}$, HE Ellens ${ }^{3}$, VE Mooser', LR Cardon', \\ CF Spraggs' and L Pandite ${ }^{2}$
}

'GlaxoSmithKline, Research and Development, Genetics Division, New Frontiers Science Park (North), Room H30-2-060, Third Avenue, Harlow, Essex CMI9 5AW, UK; ' ${ }^{2}$ GlaxoSmithKline, Oncology Research and Development, 5 Moore Drive, 17.2266B, Research Triangle Park, NC 27709, USA;

${ }^{3}$ GlaxoSmithKline, Drug Metabolism and Pharmacokinetics, 709 Swedeland Road, King of Prussia, PA 19403, USA

\begin{abstract}
BACKGROUND: Pazopanib has shown clinical activity against multiple tumour types and is generally well tolerated. However, isolated elevations in transaminases and bilirubin have been observed. This study examined polymorphisms in molecules involved in pharmacokinetic and pharmacodynamic pathways of pazopanib and their association with hepatic dysfunction.

METHODS: Twenty-eight polymorphisms in II genes were evaluated in pazopanib-treated renal cell carcinoma patients. An exploratory analysis was conducted in I 6 patients from a phase II study; a replication study was conducted in I30 patients from a phase III study.

RESULTS: No polymorphisms were associated with alanine aminotransferase elevation. The Gilbert's uridine-diphosphoglucuronate glucuronosyltransferase IAI (UGTIAI) TA-repeat polymorphism was significantly associated with pazopanib-induced hyperbilirubinemia in the phase II study. This association was replicated in the phase III study $(P<0.01)$. Patients with TA6/TA6, TA6/TA7, and TA7/TA7 genotypes experienced median bilirubin increases of $0.31,0.37$, and $0.71 \times$ upper limit of the normal range (ULN), respectively. Of the 38 patients with hyperbilirubinemia $(\geqslant 1.5 \times \cup L N), 32(84 \%)$ were either TA7 homozygotes $(n=18)$ or TA7 heterozygotes $(n=14)$. For TA7 homozygotes, the odds ratio $(95 \% \mathrm{Cl})$ for developing hyperbilirubinemia was 13.1 (5.3-32.2) compared with other genotypes.

CONCLUSIONS: The UGTIAI polymorphism is frequently associated with pazopanib-induced hyperbilirubinemia. These data suggest that some instances of isolated hyperbilirubinemia in pazopanib-treated patients are benign manifestations of Gilbert's syndrome, thus supporting continuation of pazopanib monotherapy in this setting.

British Journal of Cancer (2010) I 02, I37 I-1377. doi: I0.1038/sj.bjc.6605653 www.bjcancer.com

Published online 13 April 2010

(c) 2010 Cancer Research UK
\end{abstract}

Keywords: alanine aminotransferase; bilirubin; pazopanib; pharmacogenetics; renal cell carcinoma; UGTIA I

Pazopanib (Votrient, GlaxoSmithKline), recently approved by the United States Food and Drug Administration (FDA) for the treatment of patients with advanced renal cell carcinoma (RCC) (GlaxoSmithKline, 2009), is an oral angiogenesis inhibitor targeting vascular endothelial growth factor receptors-1, -2 , and -3 ; platelet-derived growth factor receptors- $\alpha$ and $-\beta$; and the stem cell factor receptor, c-kit (Sonpavde and Hutson, 2007). It is currently under clinical development for the treatment of multiple tumour types (Altorki et al, 2008; Friedlander et al, 2008; Sleijfer et al, 2009; Taylor et al, 2009; Sternberg et al, 2010). Clinical meaningful efficacy was observed in pazopanib-treated patients with RCC (Hutson et al, 2010; Sternberg et al, 2010). The safety profile of pazopanib was generally acceptable and tolerable. The most common adverse events were diarrhoea, hypertension, hair colour changes, nausea, anorexia, and vomiting (Sternberg et al, 2010). Elevations of liver transaminases were the most common treatment-emergent laboratory abnormalities (Sternberg et al,

*Correspondence: Dr C-F Xu; E-mail: chun-fang.2.xu@gsk.com Received 18 November 2009; revised II March 2010; accepted I8 March 2010; published online 13 April 2010
2010). Elevations in alanine aminotransferase (ALT) $>3 \times$ upper limit of the normal range (ULN) occurred in $18 \%$ of the pazopanib-treated RCC patients. Isolated elevations of total bilirubin (TBL) $>1.5 \times$ ULN were seen in $17 \%$ of pazopanibtreated RCC patients. Elevations in liver enzymes were generally asymptomatic and reversible and concurrent elevations in both ALT and bilirubin were rare. As the aetiology and mechanism of liver enzyme elevation in pazopanib-treated patients remain unknown, recommended management guideliness are based on analysis of data from clinical trials.

Treatment-associated elevations in transaminases and bilirubin have been reported with other tyrosine kinase inhibitors including sunitinib, lapatinib, and erlotinib (Motzer et al, 2007; Loriot et al, 2008; Ryan et al, 2008), and the incidence varies with agent. It is possible that these treatment-associated elevations in liver enzymes observed with tyrosine kinase inhibitors reflect overlapping on-target and off-target class effects; however, specific mechanisms remain to be elucidated. Abnormalities in clinical liver chemistry measurements are important safety signals for liver injury and may lead to treatment discontinuation, thereby compromising the potential treatment benefit to the patient. Understanding the underlying mechanisms of liver chemistry 
abnormalities may enable better interpretation and clinical management of these safety signals, and in appropriate circumstances, allow patients to benefit from continued anticancer treatment.

We sought to identify genetic markers in selected candidate genes involved in pazopanib metabolism and pharmacodynamics that may predict risk of ALT and/or bilirubin elevation on treatment. Pazopanib is a substrate for p-glycoprotein and breast cancer-resistant protein, an inhibitor of the human uptake transporter OATP1B1, and an inhibitor of uridine-diphosphoglucuronate glucuronosyltransferase $1 \mathrm{~A} 1$ (UGT1A1). It is predominately metabolised by CYP3A4 with a minor contribution from CYP2C8 and CYP1A2. Functional polymorphisms in these genes as well as in pazopanib target genes were evaluated using data from two clinical studies that evaluated the efficacy and safety of pazopanib in patients with advanced metastatic RCC (Hutson et al, 2010; Sternberg et al, 2010).

\section{MATERIALS AND METHODS}

The protocol and informed consent forms were reviewed and approved by Institutional Review Boards/Independent Ethics Committees according to local guidelines. Clinical studies were conducted in accordance with the Declaration of Helsinki. Written informed consent for participation in the clinical studies was obtained from all patients, and an additional informed consent for pharmacogenetics (PGx) research was obtained for participation in the genetic study.

\section{Patients}

The phase II RCC study (VEG102616, Study 1) had 225 participants (Hutson et al, 2010) and the phase III RCC study (VEG105192, Study 2) had 435 participants (Sternberg et al, 2010). All patients from Study 1 and 290 patients from Study 2 received pazopanib ( $800 \mathrm{mg}$ daily); the remaining 145 patients in Study 2 were randomised to the placebo arm. To minimise the effect of genetic heterogeneity among ethnic groups on the statistical analyses, the present PGx analyses were performed using the selfreported 'white' patients of European heritage, which represented the largest subgroup in each of the clinical studies. There were 156 self-reported white patients in Study 1, of whom 116 provided written informed consent for genetic research and had sufficient DNA for genotyping. There were 204 self-reported white patients in Study 2 who received pazopanib, of whom 130 provided written informed consent for genetic research and had sufficient DNA for genotyping. The present $\mathrm{PGx}$ analysis population, therefore, consisted of data from the 116 white patients from Study 1 and 130 white patients from Study 2 who received pazopanib and had genotypic data for at least one of the genetic markers evaluated (Figure 1).

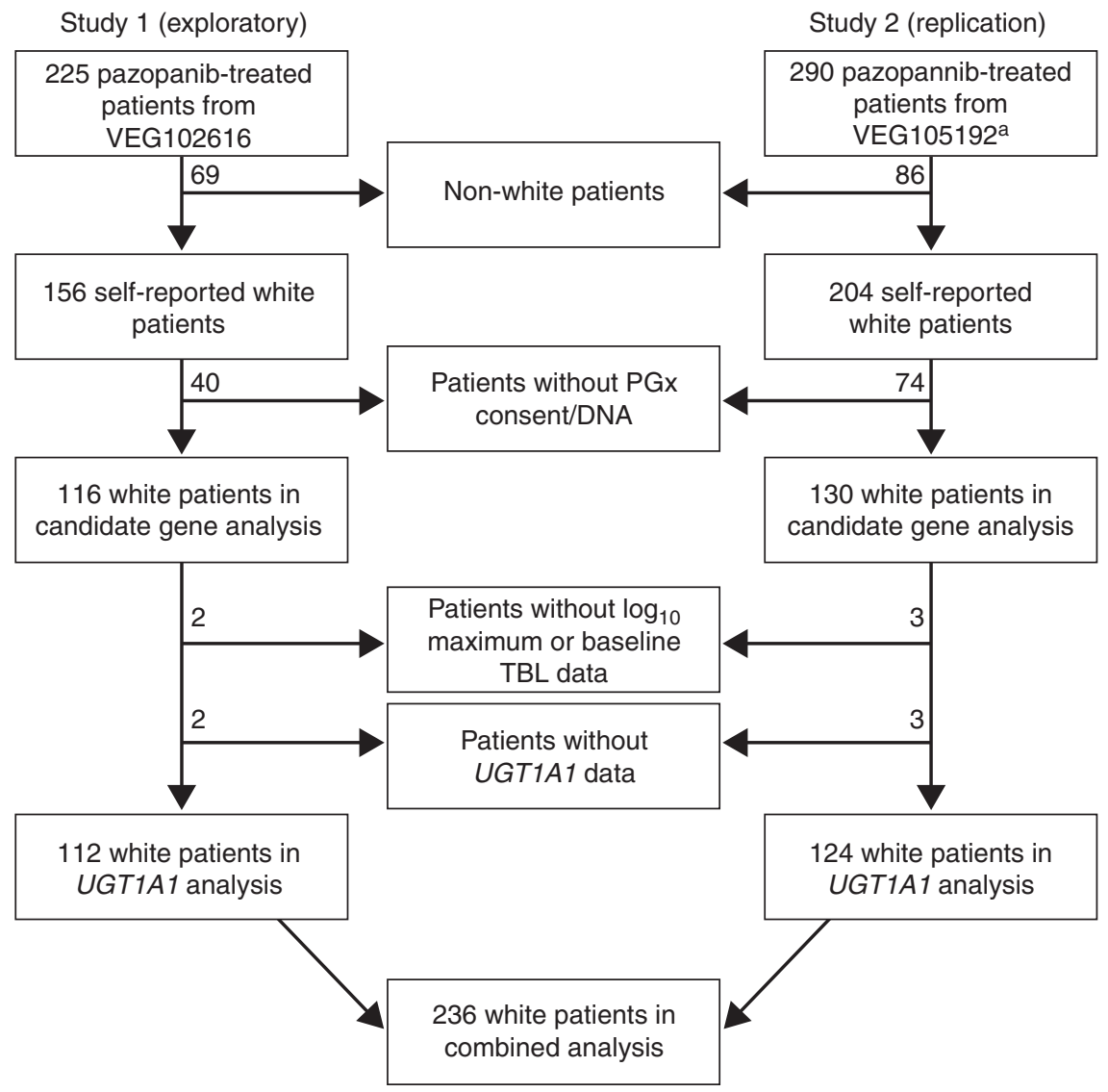

a 145 patients from VEG105192 were randomized to the placebo arm.

Figure I Patient disposition. Of the 225 pazopanib-treated patients in Study I (VEG 102616) and the 290 pazopanib-treated patients in Study 2 (VEGI05 I92), III and I24 patients, respectively, were included in the UGTIA I pharmacogenetics (PGX) analysis. These patients were self-reported to be white, provided consent for the PGx analysis, had sufficient DNA for genotyping and valid genotypic data for the UGTIAI TA-repeat polymorphism, and had baseline and on-treatment total bilirubin (TBL) data. 


\section{Liver chemistry measurements}

Alanine aminotransferase and bilirubin measurements were performed by local institutional laboratories. Both ALT and TBL values were converted to ULN by dividing the laboratory value by the institutional ULN. None of the patients from either study had a baseline ALT level $>3 \times$ ULN or baseline bilirubin level $>1.5 \times$ ULN.

\section{Genetic polymorphisms and genotyping}

Twenty-eight genetic polymorphisms in 11 genes involved in the pharmacokinetics and pharmacodynamics of pazopanib were selected (Table 1). The selection was based on reported associations or assumed functional changes of the polymorphisms to the expression or activity of the proteins.

The DNA was extracted from blood using the Qiagen (Valencia, CA, USA) QiAmp DNA Blood kit. The UGT1A1 TA-repeat polymorphism (rs8175347) was genotyped using the FDAapproved Third Wave Invader Assay, which called two alleles: the TA6 $\left({ }^{*} 1\right)$ allele and the TA7 $\left({ }^{*} 28\right)$ allele. In the rare instance when a patient had a TA-repeat number that was not 6 or $7(<1 \%)$, the genotype call for that patient was treated as missing data. The remaining polymorphisms were genotyped using Illumina (San Diego, CA, USA) GoldenGate platform (Fan et al, 2003), a single base chain extension assay modified by GlaxoSmithKline (Research Triangle Park, NC, USA) (Taylor et al, 2001), TaqMan SNP Genotyping assays (Applied Biosystems, Foster City, CA, USA; Livak et al, 1995), or sequencing.

\section{In vitro UGT1A1 inhibition}

The activity of human UGT1A1 was measured in the absence and presence of pazopanib. Human UGT1A1 Supersomes (BD Gentest, BD Biosciences, San Jose, CA, USA) were preincubated in duplicate

Table I Polymorphisms evaluated in pazopanib-treated white patients with renal cell carcinoma

\begin{tabular}{|c|c|c|c|}
\hline Gene & Polymorphism & rs number & Reference \\
\hline CYPIA2 & $\begin{array}{l}-163 \mathrm{C} / \mathrm{A} \\
-729 \mathrm{C} / \mathrm{T}\end{array}$ & $\begin{array}{c}r s 76255 \mid \\
r s|272046|\end{array}$ & $\begin{array}{l}\text { Han et al (2002) } \\
\text { Aklillu et al (2003) }\end{array}$ \\
\hline CYP3A4 & $-392 \mathrm{~A} / \mathrm{G}$ & rs2740574 & $\begin{array}{l}\text { Rodriguez-Antona } \\
\text { et al (2005) }\end{array}$ \\
\hline CYP3A5 & $\begin{array}{c}\text { 6986A/G } \\
27289 \mathrm{C} / \mathrm{A}(\mathrm{T} 398 \mathrm{~N})\end{array}$ & $\begin{array}{c}\text { rs776746 } \\
\text { rs28365083 }\end{array}$ & $\begin{array}{l}\text { Wong et al (2004) } \\
\text { Jounaidi et al (1996) }\end{array}$ \\
\hline CYP2C8 & $\begin{array}{l}\text { 805A/T (I269F) } \\
1196 \mathrm{~A} / \mathrm{G}(\mathrm{K} 399 \mathrm{R}) \\
792 \mathrm{ClG}(\mathrm{I} 264 \mathrm{M})\end{array}$ & $\begin{array}{l}\text { rs }|1572| 03 \\
\text { rs } 1050968 \mid \\
\text { rs } 1058930\end{array}$ & $\begin{array}{l}\text { Dai et al (200I) } \\
\text { Bahadur et al (2002) }\end{array}$ \\
\hline$A B C B I$ & $\begin{array}{c}-129 \mathrm{~T} / \mathrm{C} \\
\text { I } 236 \mathrm{~T} / \mathrm{C} \\
2677 \mathrm{G} / \mathrm{T} / \mathrm{A}(\mathrm{A} 893 \mathrm{~S} / \mathrm{T}) \\
3435 \mathrm{C} / \mathrm{T}\end{array}$ & $\begin{array}{l}\text { rs3213619 } \\
\text { rs 1 } 128503 \\
\text { rs2032582 } \\
\text { rs1045642 }\end{array}$ & Kerb (2006) \\
\hline$A B C G 2$ & $\begin{array}{c}\text { 34G/A (VI2M) } \\
42 I \mathrm{C} / \mathrm{A}(\mathrm{Q}|4| \mathrm{K})\end{array}$ & $\begin{array}{l}\text { rs223|137 } \\
\text { rs223||42 }\end{array}$ & $\begin{array}{l}\text { Mizuarai et al (2004) } \\
\text { Morisaki et al (2005) }\end{array}$ \\
\hline UGTIAI & $\begin{array}{c}\text { TA6/TA7 (*28) } \\
-3279 T / G(* 60) \\
2 \text { IIG/A (G7IR) (*6) }\end{array}$ & $\begin{array}{l}\text { rs8175347 } \\
\text { rs4148323 } \\
\text { rs41 } 24874\end{array}$ & $\begin{array}{l}\text { Bosma et al (1995) } \\
\text { Sugatani et al (2002) } \\
\text { Aono et al (1993) }\end{array}$ \\
\hline$S L C O|B|$ & $\begin{array}{l}388 \mathrm{~A} / \mathrm{G}(\mathrm{N} / 30 \mathrm{D}) \\
521 \mathrm{~T} / \mathrm{C}(\mathrm{V} \mid 74 \mathrm{~A})\end{array}$ & $\begin{array}{l}\text { rs2306283 } \\
\text { rs4149056 }\end{array}$ & Nozawa et al (2002) \\
\hline VEGFA & $\begin{array}{c}-2578 \mathrm{C} / \mathrm{A} \\
-1498 \mathrm{C} / \mathrm{T} \\
11154 \mathrm{G} / \mathrm{A} \\
-634 \mathrm{G} / \mathrm{C} \\
936 \mathrm{C} / \mathrm{T}\end{array}$ & $\begin{array}{l}\text { rs699947 } \\
\text { rs83306I } \\
\text { rs } 1570360 \\
\text { rs2010963 } \\
\text { rs3025039 }\end{array}$ & Schneider et al (2008) \\
\hline VEGFR2 & $\begin{array}{l}\text { 889G/A (V297I) } \\
\text { I4I6A/T (Q472H) }\end{array}$ & $\begin{array}{l}\text { rs2305948 } \\
\text { rs1870377 }\end{array}$ & \\
\hline$H I F / \alpha$ & $\begin{array}{l}\text { I772C/T (P582S) } \\
\text { I790G/A (A588T) }\end{array}$ & $\begin{array}{l}\text { rs | I } 549465 \\
\text { rs | I } 549467\end{array}$ & Tanimoto et al (2003) \\
\hline
\end{tabular}

for $5 \mathrm{~min}$ at $37^{\circ} \mathrm{C}$ in the presence of the pore-former alamethicin, the UGT1A1 substrate 7-hydroxy-4-(trifluoromethyl) coumarin (HFC), and pazopanib concentrations ranging from 0 to $250 \mu \mathrm{M}$. At the end of preincubation, the enzymatic reaction was initiated by adding the cofactor uridine $5^{\prime}$-diphosphoglucuronic acid (UDPGA). The reaction was terminated after an additional 10 min by adding acetonitrile/acetic acid (94/6 [v/v]), followed by centrifugation to sediment-precipitated protein. The production of the HFC metabolite 4-trifluoromethylumbelliferyl glucuronide (HFC-gluc) in each supernatant was quantified by HPLC-UV, and the half-maximal inhibitory concentration $\left(\mathrm{IC}_{50}\right)$ value for inhibition of UGT1A1 activity was determined. Incubations without pazopanib were performed in the presence and absence of UDPGA to confirm production of the UDPGA-dependent glucuronide metabolite HFC-gluc. Incubations without probe substrate (HFC) were performed to determine any potential assay interference by pazopanib. The $\mathrm{IC}_{50}$ of curcumin, a positivecontrol inhibitor, was determined in parallel incubations in which pazopanib was replaced with appropriate concentrations of curcumin.

\section{In vitro OATP1B1 inhibition}

Inhibition of uptake of the OATP1B1 probe substrate $\left[{ }^{3} \mathrm{H}\right]-$ estradiol $17 \beta$-D-glucuronide $\left(\left[{ }^{3} \mathrm{H}\right]-\mathrm{EG}\right)$ by pazopanib was measured using a stably transfected CHO cell line. The CHO-OATP1B1 cells were cultured to confluency, trypsinised, and seeded into 24-well assay plates (Becton, Dickinson and Company, Franklin Lakes, NJ, USA) at a density of 70000 cells $\mathrm{cm}^{-2}$ in Dulbecco's Modified Eagle Medium (DMEM) with GlutaMAX, 10\% (v/v) foetal bovine serum, $0.5 \%(\mathrm{v} / \mathrm{v})$ penicillin/streptomycin 10000 units $\mathrm{ml}^{-1}$, $0.1 \% \quad(\mathrm{v} / \mathrm{v})$ L-proline $50 \mathrm{mg} \mathrm{m}^{-1}$, and $0.7 \% \quad(\mathrm{v} / \mathrm{v})$ geneticin $50 \mathrm{mg} \mathrm{ml}^{-1}$. The cell monolayers were used 2 days after seeding and induced for at least $24 \mathrm{~h}$ before use with the addition of DMEM containing sodium butyrate (final concentration, $5 \mathrm{~mm}$ ). In the inhibition studies, CHO-OATP1B1 monolayers were preincubated $\left(37^{\circ} \mathrm{C}\right)$ for $15-30 \mathrm{~min}$ in $1 \mathrm{ml}$ of Dulbecco's Phosphate-Buffered Saline (DPBS) with the appropriate concentration of pazopanib. Triplicate wells were used for each concentration of test compound. After removal of preincubation solution, $400 \mu$ of DPBS containing the radiolabelled probe substrate and the appropriate concentrations of pazopanib was added to the wells and the cells were incubated at $37^{\circ} \mathrm{C}$ for $5 \mathrm{~min}$. The solution was then removed and the wells rinsed rapidly three times using $800 \mu$ l cold $\left(4^{\circ} \mathrm{C}\right)$ DPBS before solubilisation with $500 \mu \mathrm{l}$ of $1 \%(\mathrm{v} / \mathrm{v})$ Triton X-100. Total radioactivity was determined by scintillation counting.

\section{Statistical analysis}

The data were analysed both as continuous variables in a quantitative trait analysis (QTA) and as discrete values according to predefined thresholds in a case-control analysis. All analyses were performed in SAS version 9.1.3 (SAS Institute, Cary, NC, USA). The QTA was performed using an analysis of covariance model to assess the effect of genetic factors on baseline, maximum on-treatment, and change from baseline (delta) values for ALT and TBL. In the analyses of maximum on-treatment ALT and maximum on-treatment TBL, baseline was included in the model as a covariate. A $\log _{10}$-transformation was performed on the ALT and TBL values and a rank transformation was performed on the change-from-baseline values to correct for skewness of the data.

For case-control association analysis, a patient was defined as an ALT 'case' if one or more ALT measurements were $\geqslant 3 \times$ ULN during dosing with pazopanib. A patient was classified as an ALT 'control' if all ALT measurements were within the normal range $(\leqslant 1 \times$ ULN). A patient was defined as a TBL 'case' if one or more TBL measurements were $\geqslant 1.5 \times$ ULN during exposure to pazopanib, and a TBL 'control' if all measurements were within the 
normal range $(\leqslant 1 \times \mathrm{ULN})$. The effect of a genetic polymorphism on ALT or TBL was assessed using Fisher's exact test.

The initial exploratory analysis was performed using data from the phase II study (Study 1; VEG102616) and the replication analysis was conducted using data from the phase III study (Study 2; VEG105192). Correction for multiple tests was not performed. Instead, a threshold of $P<0.01$ was used to determine statistical significance in each study. A marker was 'replicated' when it was identified to be statistically significant in Study 1 followed by replication in Study 2. For replicated markers, a combined analysis using data from both studies was carried out to evaluate the overall effect.

\section{RESULTS}

Demographic and baseline characteristics for patients included in the present PGx investigation from Study 1 and Study 2 are shown in Table 2. None of the patients included in the PGx analysis had a baseline ALT level $>3 \times$ ULN or baseline bilirubin level $>1.5 \times$ ULN. Exploratory analyses of the effects of the 28 genetic polymorphisms on maximum ALT and bilirubin were first examined using data from Study 1 . None of the markers were significantly associated with maximum ALT $(P<0.01)$, and three markers in the UGT1A1 and CYP1A2 loci were significantly associated with maximum bilirubin $(P<0.01)$. The markers from the UGT1A1 locus were the TA-repeat polymorphism $\left(U G T 1 A 1^{\star} 28\right)$ and the $-3279 \mathrm{~T} / \mathrm{G}$ polymorphism (UGT1A ${ }^{\star} 60$ ), and the marker from the CYP1A2 locus was the $-163 \mathrm{C} / \mathrm{A}$ polymorphism (Table 1).

Replication analyses of the three significant TBL markers identified in Study 1 were performed using data from Study 2. Only the TA-repeat polymorphism from the UGT1A1 gene was replicated $(P<0.01)$. This polymorphism was not associated with maximum ALT measurements in either study.

Data from both studies were subsequently combined to determine the overall effect of the UGT1A1 TA-repeat polymorphism on bilirubin levels. Of the 246 patients included in this PGx

Table 2 Demographic and baseline characteristics for patients in the PGx study

\begin{tabular}{|c|c|c|}
\hline Characteristics & $\begin{array}{l}\text { Study I } \\
(n=I \mid 6)\end{array}$ & $\begin{array}{c}\text { Study } 2 \\
(n=130)\end{array}$ \\
\hline Age, mean years (s.d.) & $61.1(10.2)$ & $60.3(9.1)$ \\
\hline Male gender, n (\%) & $78(67)$ & $93(72)$ \\
\hline BMI, mean (s.d.) & $28.5(6.4)$ & $27.1(5.1)$ \\
\hline Liver metastases, yes (\%) & $21(18)^{a}$ & $34(26)$ \\
\hline \multicolumn{3}{|l|}{ ECOG, $n(\%)$} \\
\hline 0 & $74(64)$ & $46(35)$ \\
\hline 1 & $42(36)$ & $84(65)$ \\
\hline \multicolumn{3}{|l|}{ MSKCC risk category, n (\%) } \\
\hline Favourable & $53(46)$ & $51(39)$ \\
\hline Intermediate & $45(39)$ & $72(55)$ \\
\hline Poor & $3(3)$ & $2(2)$ \\
\hline Unknown & $15(13)$ & $5(4)$ \\
\hline Earlier nephrectomy, n (\%) & $97(84)$ & I 16 (89) \\
\hline $\begin{array}{l}\text { Baseline ALT } \times \text { ULN, median } \\
\text { (25th, 75th percentile) }\end{array}$ & $0.5(0.3,0.6)$ & $0.4(0.3,0.7)$ \\
\hline $\begin{array}{l}\text { Baseline TBL } \times \text { ULN, median } \\
\text { (25th, 75th percentile) }\end{array}$ & $0.5(0.3,0.6)$ & $0.5(0.3,0.6)$ \\
\hline
\end{tabular}

Abbreviations: $A L T=$ alanine aminotransferase; $\mathrm{BMI}=$ body mass index; $\mathrm{ECOG}$ PS = Eastern Cooperative Oncology Group performance status; $M S K C C=$ Memorial Sloan-Kettering Cancer Center; PGx = pharmacogenetics; s.d. = standard deviation; $\mathrm{TBL}=$ total bilirubin; $\mathrm{ULN}=$ upper limit of normal range. ${ }^{\mathrm{a}}$ Two patients from Study I did not have information for baseline liver metastases. analysis, data for bilirubin and the UGT1A1 TA-repeat marker were obtained for 236 patients (Figure 1). Of the remaining 10 patients, 5 had missing UGT1A1 genotype data and 5 had missing $\log _{10}$-transformed maximum or baseline TBL data. As expected, a significant association between the UGT1A1 TArepeat polymorphism and maximum bilirubin was observed $\left(P=1.6 \times 10^{-6}\right.$ and $P=1.8 \times 10^{-8}$ for the QTA and case-control analysis, respectively). The median values of maximum bilirubin were $0.75 \times \mathrm{ULN}, 0.87 \times \mathrm{ULN}$, and $1.40 \times \mathrm{ULN}$ for patients with the TA6/TA6, TA6/TA7, and TA7/TA7 genotypes, respectively. Moreover, this polymorphism was significantly associated with bilirubin increases from baseline (delta) during pazopanib treatment $\left(P=4.5 \times 10^{-5}\right)$. The median bilirubin increases were $0.31 \times \mathrm{ULN}$, $0.37 \times \mathrm{ULN}$, and $0.71 \times \mathrm{ULN}$ for pazopanib-treated patients with the TA6/TA6, TA6/TA7, and TA7/TA7 genotypes, respectively. Thus, the median on-treatment bilirubin increase for TA7 homozygotes was 2.3-fold greater than the increase observed for the TA6 homozygotes (Figure 2).

Compared with the TA6/TA6 and TA6/TA7 genotypes, the odds ratio ( $95 \%$ confidence interval), positive predictive value, and negative predictive value for TA7/TA7 genotype were 13.1 $(5.3-32.2), 0.49$, and 0.90 , respectively. The incidence of hyperbilirubinemia was $49 \%$ (18 of 37) for patients with the TA7/TA7 genotypes and $12 \%$ (14 of 113 ) for patients with the TA6/TA7 genotypes (Figure 3). In contrast, pazopanib-related incidence of hyperbilirubinemia was only $7 \%$ (6 of 86$)$ for patients with the TA6/TA6 genotype. Of the 38 cases of TBL elevation, 32 patients $(84 \%)$ were either TA7 homozygotes $(n=18,47 \%)$ or TA7 heterozygotes $(n=14,37 \%)$.

The ability of pazopanib to inhibit the two major determinants of serum bilirubin levels, UGT1A1 and OATP1B1, was measured. Pazopanib was shown to be a potent inhibitor of UGT1A1 as well as OATP1B1, with $\mathrm{IC}_{50}$ of 1.2 and $0.79 \mu \mathrm{M}$, respectively (Figure 4 ).

\section{DISCUSSION}

This study shows that both maximum on-treatment bilirubin concentration and bilirubin increase from baseline were strongly associated with the UGT1A1 TA-repeat polymorphism. None of the

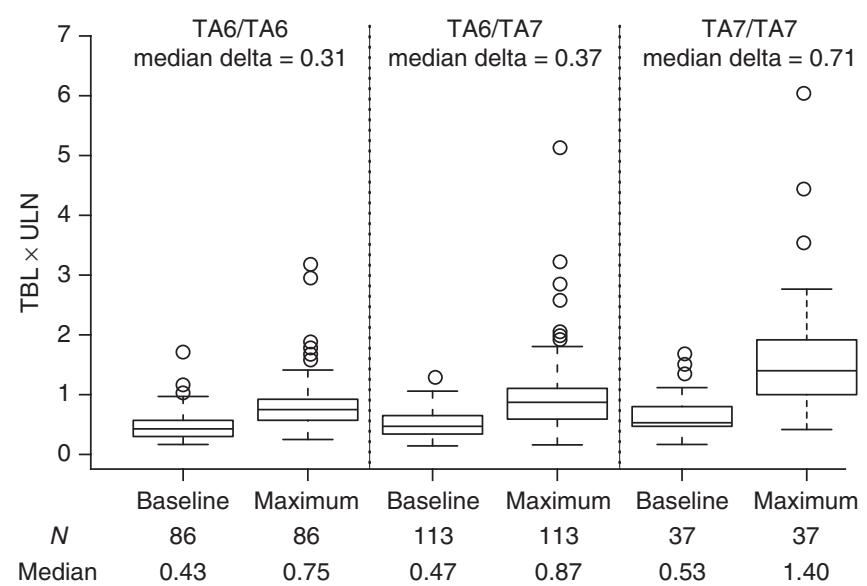

Figure 2 The distribution of baseline total bilirubin (TBL) and maximum TBL by UGTIAI TA-repeat genotype for pazopanib-treated white patients from both Study I and Study 2. The maximum bilirubin value for one patient who had the TA7/TA7 genotype was truncated from $19 \times$ upper limit of normal (ULN) to $6 \times$ ULN for viewing purposes. The number of patients with each genotype, and the median values for baseline TBL, maximum TBL, and maximum change-from-baseline (delta) $T B L$ are provided. The variation in baseline TBL, maximum TBL, and change-frombaseline TBL by genotype is statistically significant for each end point: $P=4.0 \times 10^{-3}, 1.6 \times 10^{-6}$, and $4.5 \times 10^{-5}$, respectively. 
genetic markers evaluated were predictive of ALT elevation. Bilirubin is metabolised by UGT1A1 for elimination. The UGT1A1 genetic variant TA7 is known to cause reduced expression of UGT1A1 (Bosma et al, 1995), and the TA7/TA7 $\left(* 28 /{ }^{*} 28\right)$ genotype predisposes individuals to Gilbert's syndrome, a benign form of episodic jaundice (Bosma et al, 1995; Raijmakers et al, 2000). This UGT1A1 TA-repeat polymorphism has also been reported to be associated with hyperbilirubinemia induced by several drugs, such as tranilast, nilotinib, and indinavir (Zucker et al, 2001; Danoff et al, 2004; Singer et al, 2007). Pazopanib is a potent inhibitor of UGT1A1 activity in vitro, with an $\mathrm{IC}_{50}$ of $1.2 \mu \mathrm{M}$. Thus, this study suggests that pazopanib-induced hyperbilirubinemia may be the result of inhibition of UGT1A1 activity combined with genetic defects of the UGT1A1 gene. This would presumably result in higher levels of unconjugated hyperbilirubinemia, usually associated with a benign clinical course. It is possible that bilirubin elevation associated with other tyrosine kinase inhibitors such as sunitinib, lapatinib, and erlotinib may also be related to UGT1A1 genotype. However, to our knowledge, data from genetic investigations for drug-induced hyperbilirubinemia for these compounds are not yet available.

We observed that $6(16 \%)$ of the 38 patients who had isolated hyperbilirubinemia had the TA6/TA6 genotype, suggesting that additional factors may contribute to bilirubin elevation in pazopanib-treated patients. Concurrent elevations of

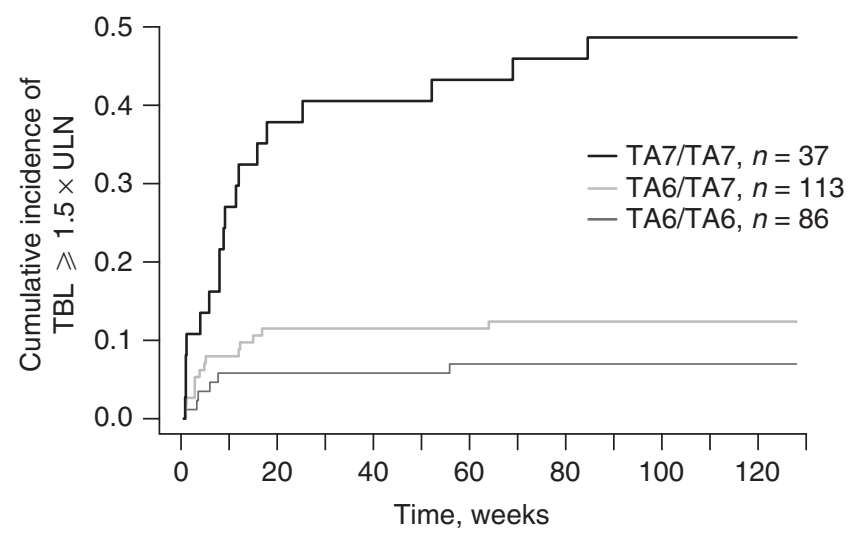

Figure 3 Cumulative incidence of hyperbilirubinemia $(\geqslant 1.5 \times$ upper limit of normal [ULN]) by UGTIAI TA-repeat genotype for pazopanibtreated white patients from both Study I and Study 2 . The cumulative incidence of total bilirubin (TBL) $\geqslant 1.5 \times$ ULN for each genotype group at a time point (weeks) is the proportion of patients from the group who had at least one on-treatment TBL value of $1.5 \times U L N$ or greater on or before the time point. transaminases were not seen in these six patients. A recent genome-wide association study identified OATP1B1 (alternative symbol $S L C O 1 B 1$ ) as one of the top loci associated with bilirubin levels (Johnson et al, 2009). Genetic markers in the OATP1B1 gene were also evaluated in this study and were not found to be associated with pazopanib-related bilirubin elevation. As pazopanib is also a potent inhibitor of OATP1B1 (in vitro), we cannot exclude the possibility that pazopanib-induced hyperbilirubinemia may be the result of inhibition of both OATP1B1 and UGT1A1 activity combined with genetic defects of the UGT1A1 gene. The lack of association with genetic markers in the OATP1B1 gene may stem from the fact that pazopanib inhibited hepatic uptake of bilirubin to the same level in both wild type and variant forms.

Among the 246 patients evaluated in this study, concurrent elevation of ALT and bilirubin was observed in one patient (0.4\%). This patient was heterozygous (TA6/TA7) for the UGT1A1 TA-repeat polymorphism and had direct bilirubin of $0.5 \mathrm{mgl}^{-1}$, representing $22 \%$ of TBL $\left(2.3 \mathrm{mg} \mathrm{dl}^{-1}\right)$. Reduced UGT1A1 activity, both as a result of pazopanib inhibition of UGT1A1 and the genetic defect of the UGT1A1 gene, may have contributed to the bilirubin elevation observed in this patient. Concurrent elevations in ALT and bilirubin levels after pazopanib treatment could indicate liver toxicity (Kaplowitz, 2006); therefore, it is important to rule out this possibility to allow continued treatment. This is particularly important because continued anticancer treatment may allow for more favourable clinical outcomes and should be feasible in patients with benign hyperbilirubinemia, as might be the case for most pazopanib-treated patients. It follows that, for each patient, the clinical management of hepatotoxicity needs to be tailored according to the severity and impact of this adverse effect on the patient. In addition, the mechanisms involved in the observed elevation in transaminases and bilirubin should also be considered.

This study focused on data from trials evaluating pazopanib monotherapy in patients with RCC. The observed elevation in ALT or bilirubin levels was not associated with liver metastasis for patients included in the present PGx analysis. The full implications of these findings for regimens combining pazopanib with other agents are currently unknown. Clearly, it is important for clinicians to be aware of potential drug-drug interactions, particularly with compounds known to be metabolised and eliminated predominantly through the UGT1A1 pathway. Therefore, concomitant administration of pazopanib and UGT1A1 substrates that have narrow therapeutic index should be undertaken with caution. Pazopanib itself is not known to be subject to significant glucuronidation by UGT1A1. It is, therefore, unlikely that defective UGT1A1 would have a direct impact on the exposure of pazopanib and, therefore, exposure-related toxicities.
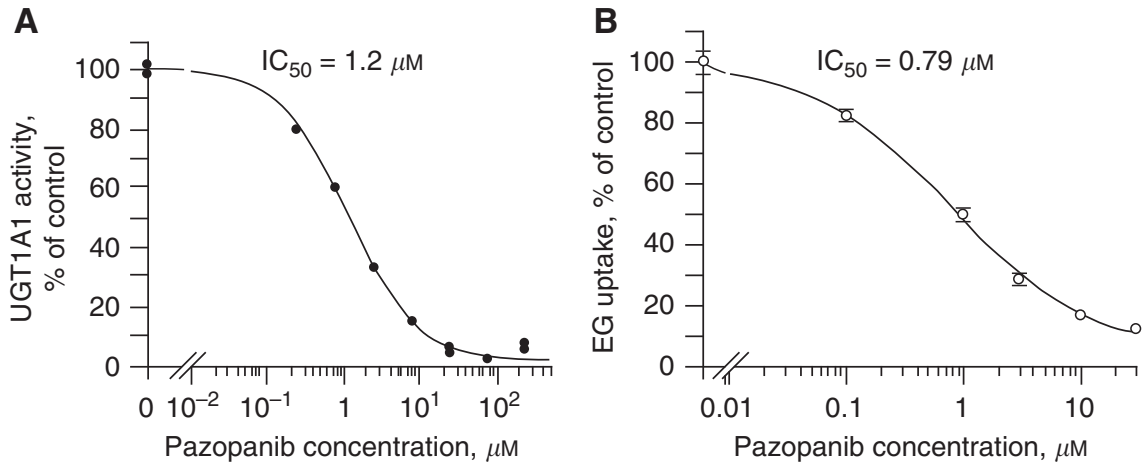

Figure 4 Pazopanib inhibition of UGTIAI (A, duplicate data points) and OATPIBI (B, triplicates). EG, the OATPIBI probe substrate [ $\left.{ }^{3} \mathrm{H}\right]$-estradiol $17 \beta$-D-glucuronide; $I C_{50}$, half-maximal inhibitory concentration. 
The practical implication of our finding is for clinicians to recognise that isolated hyperbilirubinemia in pazopanib-treated patients, after exclusion of other causes such as haemolysis, seems to have a benign aetiology. Given the life-threatening nature of cancer and the benign clinical course of unconjugated hyperbilirubinemia, the data do not call for population-based prospective UGT1A1 screening to exclude patients from pazopanib monotherapy. Bilirubin fractionation should be conducted in patients who develop hyperbilirubinemia during pazopanib treatment, which could distinguish unconjugated hyperbilirubinemia from conjugated hyperbilirubinemia. The latter would require further investigation. This may help to elucidate the nature of the bilirubin elevation and might enable differentiation of the risk of progression of drug-induced liver injury. A limitation of this study is the lack of bilirubin fractionation data to allow full assessment between the UGT1A1 polymorphism and unconjugated bilirubin levels.

\section{REFERENCES}

Aklillu E, Carrillo JA, Makonnen E, Hellman K, Pitarque M, Bertilsson L, Ingelman-Sundberg M (2003) Genetic polymorphism of CYP1A2 in Ethiopians affecting induction and expression: characterization of novel haplotypes with single-nucleotide polymorphisms in intron 1 . Mol Pharmacol 64(3): 659-669

Altorki N, Heymach J, Guarino M, Lee P, Felip E, Bauer T, Swann S, Roychowdhury D, Ottesen LH, Yankelevitz D (2008) Phase II study of Pazopanib (GW786034) given preoperatively in stage i-ii non-small cell lung cancer (NSCLC): a proof-of-concept study. Ann Oncol 19 (suppl 8): viii89

Aono S, Yamada Y, Keino H, Hanada N, Nakagawa T, Sasaoka Y, Yazawa T, Sato H, Koiwai O (1993) Identification of defect in the genes for bilirubin UDP-glucuronosyl-transferase in a patient with Crigler-Najjar syndrome type II. Biochem Biophys Res Commun 197(3): 1239-1244

Bahadur N, Leathart JB, Mutch E, Steimel-Crespi D, Dunn SA, Gilissen R, Houdt JV, Hendrickx J, Mannens G, Bohets H, Williams FM, Armstrong M, Crespi CL, Daly AK (2002) CYP2C8 polymorphisms in Caucasians and their relationship with paclitaxel 6alpha-hydroxylase activity in human liver microsomes. Biochem Pharmacol 64(11): 1579-1589

Bosma PJ, Chowdhury JR, Bakker C, Gantla S, de Boer A, Oostra BA, Lindhout D, Tytgat GN, Jansen PL, Oude Elferink RP, Chowdhury NR (1995) The genetic basis of the reduced expression of bilirubin UDPglucuronosyltransferase 1 in Gilbert's syndrome. $N$ Engl J Med 333(18): $1171-1175$

Dai D, Zeldin DC, Blaisdell JA, Chanas B, Coulter SJ, Ghanayem BI, Goldstein JA (2001) Polymorphisms in human CYP2C8 decrease metabolism of the anticancer drug paclitaxel and arachidonic acid. Pharmacogenetics 11(7): $597-607$

Danoff TM, Campbell DA, McCarthy LC, Lewis KF, Repasch MH, Saunders AM, Spurr NK, Purvis IJ, Roses AD, Xu CF (2004) A Gilbert's syndrome UGT1A1 variant confers susceptibility to tranilast-induced hyperbilirubinemia. Pharmacogenomics J 4(1): 49-53

Fan JB, Oliphant A, Shen R, Kermani BG, Garcia F, Gunderson KL, Hansen M, Steemers F, Butler SL, Deloukas P, Galver L, Hunt S, McBride C, Bibikova M, Rubano T, Chen J, Wickham E, Doucet D, Chang W, Campbell D, Zhang B, Kruglyak S, Bentley D, Haas J, Rigault P, Zhou L, Stuelpnagel J, Chee MS (2003) Highly parallel SNP genotyping. Cold Spring Harb Symp Quant Biol 68: 69-78

Friedlander M, Hancock KC, Benigno B, Rischin D, Messing M, Stringer CA, Hodge JP, Ma B, Matthys G, Lager JJ (2008) Pazopanib (GW786034) is active in women with advanced epithelial ovarian, fallopian tube, and peritoneal cancers: results of a phase II study. Ann Oncol 19 (suppl 8): viii211

GlaxoSmithKline (2009) FDA approves GlaxoSmithKline's Votrient for advanced renal cell cancer. www.gsk.com/media/pressreleases/2009/ 2009_pressrelease_10113.htm

Han XM, Ouyang DS, Chen XP, Shu Y, Jiang CH, Tan ZR, Zhou HH (2002) Inducibility of CYP1A2 by omeprazole in vivo related to the genetic polymorphism of CYP1A2. Br J Clin Pharmacol 54(5): 540-543

Hutson TE, Davis ID, Machiels JP, De Souza PL, Rottey S, Hong B, Epstein RJ, Baker KL, McCann L, Crofts T, Liu Y, Pandite L, Figlin RA (2010) Efficacy and safety of pazopanib in patients with metastatic renal cell carcinoma. I Clin Oncol 28(3): 475-480

\section{ACKNOWLEDGEMENTS}

We thank the investigators and their patients who made this study possible. We acknowledge Leigh Ragone, Morlisa Dixon, Bo Zheng, Nan Bing, and Keith Nangle for their excellent technical support. We thank Melissa Stutts, Vicki Goodman, Theresa Bryant, and Chris Abissi for their contribution in evaluating patients with potential hepatotoxicity; Lauren McCann and Shawn Liu for discussion of the laboratory liver chemistry data. We are grateful to Rafael Amado, Pamela StJean, Matthew Nelson, Anne Marie Martin, and Howard Ball, and the GSK hepatotoxicity board, in particular Christine Hunt and Beena Koshy, for their review and discussion of the data. Financial support for this study and medical editorial assistance was provided by GlaxoSmithKline Pharmaceuticals, Philadelphia, Pennsylvania. We thank Jerome Sah, PhD, ProEd Communications, Inc., for his medical editorial assistance with this manuscript.

Johnson AD, Kavousi M, Smith AV, Chen MH, Dehghan A, Aspelund T, Lin JP, van Duijn CM, Harris TB, Cupples LA, Uitterlinden AG, Launer L, Hofman A, Rivadeneira F, Stricker B, Yang Q, O'Donnell CJ, Gudnason V, Witteman JC (2009) Genome-wide association meta-analysis for total serum bilirubin levels. Hum Mol Genet 18(14): 2700-2710

Jounaidi Y, Hyrailles V, Gervot L, Maurel P (1996) Detection of CYP3A5 allelic variant: a candidate for the polymorphic expression of the protein? Biochem Biophys Res Commun 221(2): 466-470

Kaplowitz N (2006) Rules and laws of drug hepatotoxicity. Pharmacoepidemiol Drug Saf 15(4): $231-233$

Kerb R (2006) Implications of genetic polymorphisms in drug transporters for pharmacotherapy. Cancer Lett 234(1): 4-33

Livak KJ, Marmaro J, Todd JA (1995) Towards fully automated genomewide polymorphism screening. Nat Genet 9(4): 341-342

Loriot Y, Boudou-Rouquette P, Billemont B, Ropert S, Goldwasser F (2008) Acute exacerbation of hemorrhagic rectocolitis during antiangiogenic therapy with sunitinib and sorafenib. Ann Oncol 19(11): 1975

Mizuarai S, Aozasa N, Kotani H (2004) Single nucleotide polymorphisms result in impaired membrane localization and reduced atpase activity in multidrug transporter ABCG2. Int J Cancer 109(2): 238-246

Morisaki K, Robey RW, Ozvegy-Laczka C, Honjo Y, Polgar O, Steadman K, Sarkadi B, Bates SE (2005) Single nucleotide polymorphisms modify the transporter activity of ABCG2. Cancer Chemother Pharmacol 56(2): $161-172$

Motzer RJ, Hutson TE, Tomczak P, Michaelson MD, Bukowski RM, Rixe O, Oudard S, Negrier S, Szczylik C, Kim ST, Chen I, Bycott PW, Baum CM, Figlin RA (2007) Sunitinib versus interferon alfa in metastatic renal-cell carcinoma. $N$ Engl J Med 356(2): 115-124

Nozawa T, Nakajima M, Tamai I, Noda K, Nezu J, Sai Y, Tsuji A, Yokoi T (2002) Genetic polymorphisms of human organic anion transporters OATP-C (SLC21A6) and OATP-B (SLC21A9): allele frequencies in the Japanese population and functional analysis. J Pharmacol Exp Ther 302(2): $804-813$

Raijmakers MT, Jansen PL, Steegers EA, Peters WH (2000) Association of human liver bilirubin UDP-glucuronyltransferase activity with a polymorphism in the promoter region of the UGT1A1 gene. J Hepatol 33(3): $348-351$

Rodriguez-Antona C, Sayi JG, Gustafsson LL, Bertilsson L, IngelmanSundberg M (2005) Phenotype-genotype variability in the human CYP3A locus as assessed by the probe drug quinine and analyses of variant CYP3A4 alleles. Biochem Biophys Res Commun 338(1): $299-305$

Ryan Q, Ibrahim A, Cohen MH, Johnson J, Ko CW, Sridhara R, Justice R, Pazdur R (2008) FDA drug approval summary: lapatinib in combination with capecitabine for previously treated metastatic breast cancer that overexpresses HER-2. Oncologist 13(10): 1114-1119

Schneider BP, Wang M, Radovich M, Sledge GW, Badve S, Thor A, Flockhart DA, Hancock B, Davidson N, Gralow J, Dickler M, Perez EA, Cobleigh M, Shenkier T, Edgerton S, Miller KD (2008) Association of vascular endothelial growth factor and vascular endothelial growth factor receptor-2 genetic polymorphisms with outcome in a trial of paclitaxel compared with paclitaxel plus bevacizumab in advanced breast cancer: ECOG 2100. J Clin Oncol 26(28): $4672-4678$ 
Singer JB, Shou Y, Giles F, Kantariian HM, Hsu Y, Robeva AS, Rae P, Weitzman A, Meyer JM, Dugan M, Ottmann OG (2007) UGT1A1 promoter polymorphism increases risk of nilotinib-induced hyperbilirubinemia. Leukemia 21(11): 2311-2315

Sleijfer S, Ray-Coquard I, Papai Z, Le Cesne A, Scurr M, Schoffski P, Collin F, Pandite L, Marreaud S, De Brauwer A, van Glabbeke M, Verweij J, Blay JY (2009) Pazopanib, a multikinase angiogenesis inhibitor, in patients with relapsed or refractory advanced soft tissue sarcoma: a phase II study from the European organisation for research and treatment of cancer-soft tissue and bone sarcoma group (EORTC study 62043). J Clin Oncol 27(19): 3126-3132

Sonpavde G, Hutson TE (2007) Pazopanib: a novel multitargeted tyrosine kinase inhibitor. Curr Oncol Rep 9(2): 115-119

Sternberg CN, Davis ID, Mardiak J, Szczylik C, Lee ES, Wagstaff J, Barrios CH, Salman P, Gladkov OA, Kavina A, Zarba JJ, Chen M, McCann L, Pandite L, Roychowdhury D, Hawkins RE (2010) Pazopanib in locally advanced and/or metastatic renal cell carcinoma: results of a randomized phase III trial. J Clin Oncol 28(6): 1061-1068

Sugatani J, Yamakawa K, Yoshinari K, Machida T, Takagi H, Mori M, Kakizaki S, Sueyoshi T, Negishi M, Miwa M (2002) Identification of a defect in the UGT1A1 gene promoter and its association with hyperbilirubinemia. Biochem Biophys Res Commun 292(2): 492-497

Tanimoto K, Yoshiga K, Eguchi H, Kaneyasu M, Ukon K, Kumazaki T, Oue N, Yasui W, Imai K, Nakachi K, Poellinger L, Nishiyama M
(2003) Hypoxia-inducible factor-1alpha polymorphisms associated with enhanced transactivation capacity, implying clinical significance. Carcinogenesis 24(11): 1779-1783

Taylor JD, Briley D, Nguyen Q, Long K, Iannone MA, Li MS, Ye F, Afshari A, Lai E, Wagner M, Chen J, Weiner MP (2001) Flow cytometric platform for high-throughput single nucleotide polymorphism analysis. Biotechniques 30(3): $661-666,668-669$

Taylor SK, Chia S, Dent S, Clemons M, Grenci P, Wang L, Oza AM, Ivy P, Pritchard K, Leighl N (2009) A phase II study of GW786034 (pazopanib) in patients with recurrent or metastatic invasive breast carcinoma: results after completion of stage I: a trial of the Princess Margaret Hospital Phase II Consortium. J Clin Oncol 27(15s): abstract 1133

Wong M, Balleine RL, Collins M, Liddle C, Clarke CL, Gurney H (2004) CYP3A5 genotype and midazolam clearance in Australian patients receiving chemotherapy. Clin Pharmacol Ther 75(6): 529-538

Zucker SD, Qin X, Rouster SD, Yu F, Green RM, Keshavan P, Feinberg J, Sherman KE (2001) Mechanism of indinavir-induced hyperbilirubinemia. Proc Natl Acad Sci USA 98(22): 12671-12676

c) (1) (2) This work is licensed under the Creative Commons BY NC SA Attribution-NonCommercial-Share Alike 3.0 License. To view a copy of this license, visit http://creativecommons.org/ licenses/by-nc-sa/3.0/ 